\title{
The deep-seated lowland relict permafrost from the Suwałki region (NE Poland) - analysis of conditions of its development and preservation
}

\author{
Jan SZEWCZYK ${ }^{1, *}$
}

1 Polish Geological Institute - National Research Institute, Rakowiecka 4, 00-975, Warszawa, Poland

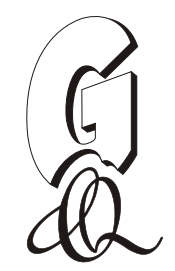

\begin{abstract}
Szewczyk, J., 2017. The deep-seated lowland relict permafrost from the Suwałki region (NE Poland) - analysis of conditions of its development and preservation. Geological Quarterly, 61 (4): 845-858, doi: 10.7306/gq.1378

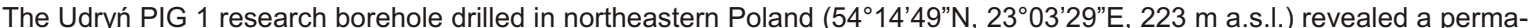
frost layer, at least $93 \mathrm{~m}$ thick, within the sedimentary succession below a depth of $357 \mathrm{~m}$. The base of the permafrost has not been reached at $450 \mathrm{~m}$ depth, where the drilling stopped, so its total present thickness remains unknown. The relict permafrost, unexpected in this part of Central Europe, is in the ice-water transition phase at a temperature slightly below the $0^{\circ} \mathrm{C}$. Analysis of geophysical and hydrogeological data indicates the possibility of preserving the permafrost in the central part of sedimentary cover of the Suwałki Anorthosite Massif over an area of probably $50 \mathrm{~km}^{2}$. Preliminary results of geothermal modelling indicate maximum palaeothickness of permafrost at the end of the Last Glacial Maximum of probably $\sim 600 \mathrm{~m}$. The development of such a thick permafrost results both from a very low average annual temperature in the Weichselian Glaciation and a very low terrestrial heat flow density. It is very probable that similar zones of deep relict permafrost occurrences, undetected so far, may exist in other areas of the Precambrian Platform not only in Poland, but also in the neighbouring countries.
\end{abstract}

Key words: relict permafrost, palaeoclimate, Weichselian Glaciation, terrestrial heat flow, cryogenic groundwater, Suwałki Anorthosite Massif.

\section{INTRODUCTION}

The discovery of deep relict permafrost in northern Poland was the result of both analyses of the subsurface geothermal regime and hydrogeological, petrophysical and geophysical data obtained mainly from wells drilled in the Suwałki Anorthosite Massif (SAM) region located in the research area. This wide, comprehensive and unique range of research has been obtained in connection with exploration of Fe-Ti-V mineral resources, conducted in the crystalline basement of NE Poland in the 1960 s to 1980 s (Ryka and Podemski, 1998).

The objective of this paper is to present a model of deep relict permafrost, its petrophysical, geothermal and hydrogeological characteristics, and to provide both climatic and geological conditions in which it was formed, and how it has survived to the present days. It also explains whether the conditions for its formation and survival existed or exist in other parts of Poland and adjacent areas.

The hypothesis about possibility of permafrost preservation in the central part of the SAM was first presented on the 2nd European Conference on Permafrost in Potsdam (Szewczyk et al., 2005). The results of studies, carried out in the Udryń PIG 1 borehole in 2010 , spectacularly confirmed this hypothesis. The

*E-mail: jan.szewczyk@pgi.gov.pl

Received: August 2, 2016; accepted: July 5, 2017; first published online: September 7, 2017 case of the SAM is unique, not only as the geological object itself, but also in terms of a broad range of geological exploration, including many hydrogeological, petrophysical and geophysical surveys. Probably, it is one of the most thoroughly studied massifs of this type in the world.

Discovery of the relict permafrost in the Suwałki region (Udryń PIG 1 borehole, NE Poland, 54¹4'49”N, 2303'29"E, $223 \mathrm{~m}$ a.s.l.) at a depth between 357 to $>450 \mathrm{~m}$ in 2010 indicates that such unexpected phenomena can occur not only elsewhere across Central and Eastern Europe but also beyond (Szewczyk and Nawrocki, 2011). The base of the permafrost has not been reached at $450 \mathrm{~m}$ depth, where the drilling was completed, so its total thickness remains unknown. The relict permafrost was found in the form of ice-water transition phase at a temperature $-0.245^{\circ} \mathrm{C}$, corresponding to the present thermodynamic conditions of its occurrence (i.e. hydrostatic pressure and chemical composition of groundwater).

Due to large predominance of cold climate periods in climatic history of the Earth during more than last 420 ka (see Petit et al., 1999), the cold state of subsurface thermal regime of the Earth is their primary quasi-stationary state to a depth of several kilometres. The comparatively short duration (10-15 ka) of the warmer interglacial periods, as Holocene or Eemian, vs. colder glacial Weichselian or Wartanian (90-95 ka), disturbed that deep, subsurface pseudo-stable thermal regime only for a relatively short period (Szewczyk and Gientka, 2009).

The creation of permafrost and its decay is a function of temperature as well as geological and petrophysical factors such as the value of terrestrial heat flow density and the presence of ice sheet cover and its thickness. The presence of ice 


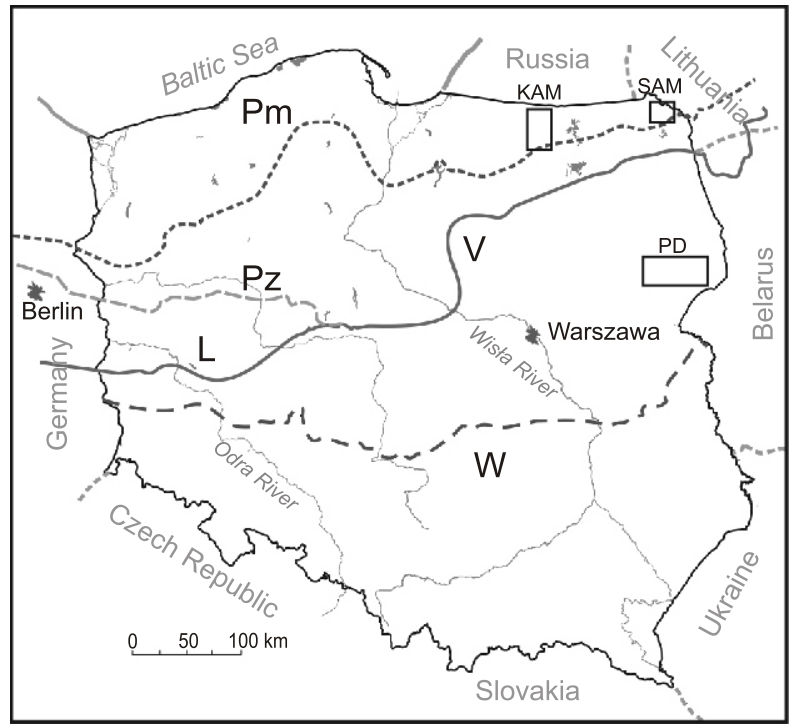

Fig. 1. Limits of the major glacial phases during the Late Weichselian/LGM (V) and Wartanian (W) in Poland and neighbouring areas (after Marks, 2005, modified and supplemented)

Ice sheet limits: L - Leszno (Brandenburg) Phase, Pz - Poznań (Frankfurt) Phase, Pm - Pomeranian Phase; main glacial lakes and location of Suwałki Anorthosite Massif (SAM) and Kętrzyn Anorthosite Massif (KAM) are shown, PD - Podlasie Depression

sheets in all cases increases the subsurface temperature leading to the reduction of thickness of the existing permafrost and even to its complete degradation.
Central Europe including Poland have repeatedly been affected by harsh periglacial climate at the forefront of the Fennoscandian ice sheets. Figure 1 shows the ice sheet limits of the major glacial phases during the Late Weichselian and Wartanian glaciations in Poland and neighbouring areas (Marks, 2005). These conditions were very favourable for the formation of continuous permafrost of considerable thickness in the area of Poland during the Weichselian glaciations. The maximum rate of its formation and thickness, the permafrost attained at the end of the LGM. The rate of its decay during the Holocene depended largely on the heat flux values.

\section{GEOTHERMAL AND HYDROGEOLOGICAL ANOMALY OF THE SUWAŁKI ANORTHOSITE MASSIF}

The Suwałki Anorthosite Massif is a magmatic intrusion covering an area of $\sim 250 \mathrm{~km}^{2}$. The depth to the crystalline basement is $800-1200 \mathrm{~m}$; it is overlain by the sedimentary succession of Paleozoic, Mesozoic and Cenozoic rocks (Fig. 2). Between 1960 and 1984, a number of deep boreholes were drilled in crystalline rocks of the SAM in the search for iron-vanadium-titanium deposits (Cieśla and Wybraniec, 1998).

Figure 3 shows the location of SAM and the similar but much greater Kętrzyn Anorthosite Massif (KAM) on the background of stable corrected temperature at a depth of $2000 \mathrm{~m}$ (i.e. below the depth interval influenced by temperature disturbances during glacial cycles; Szewczyk and Gientka, 2009; Szewczyk, 2010). This information is another important indicator of potential conditions of the creation of permafrost during the time of climate cooling related to the Weichselian Glaciation.

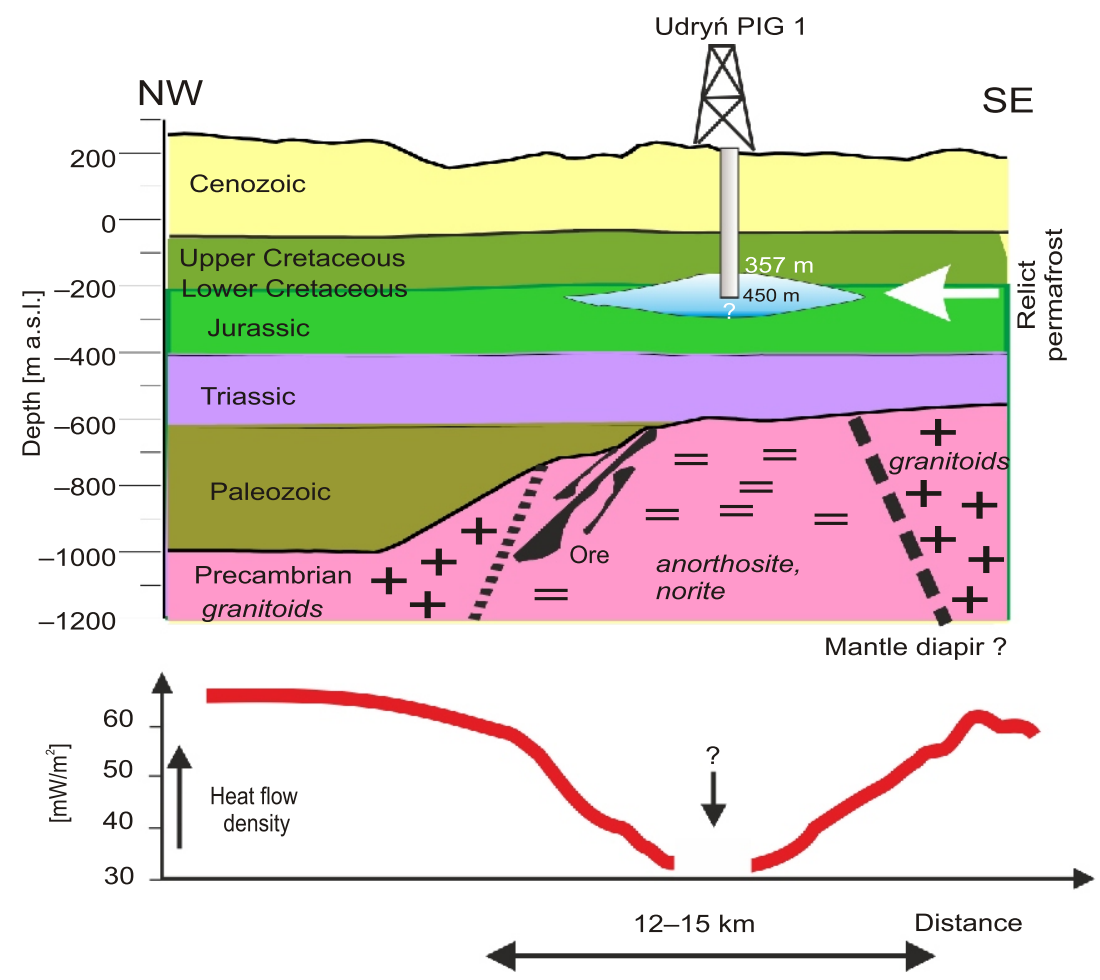

Fig. 2. Simplified schematic geological cross-section of the Suwałki Anorthosite Massif (SAM) with location of relict permafrost and Udryń PIG 1 borehole 


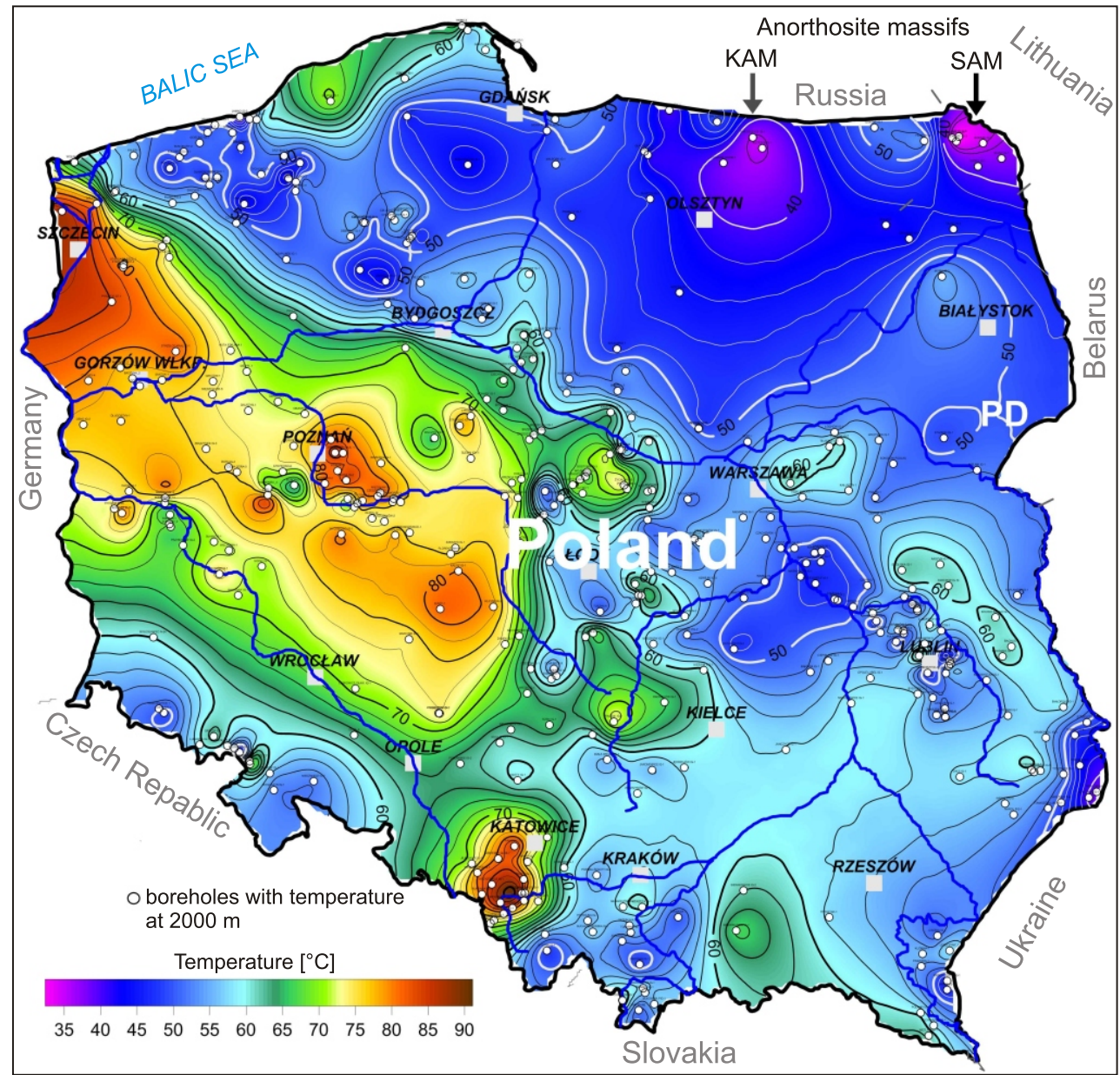

Fig. 3. Map of steady-state temperature in Poland at a depth of $2000 \mathrm{~m}$ (after Szewczyk, 2010, modified)

Location of anorthosite massifs (Suwałki and Kętrzyn) associated with thermal minima are shown; explanations as in Figure 1

A number of boreholes deeper than $2000 \mathrm{~m}$ were drilled in crystalline rocks and many shallow hydrogeological boreholes to a depth of $<300 \mathrm{~m}$ in the sedimentary cover. The temperature logs performed in these boreholes indicated temperature inversion within the depth interval of 350-450 m (Majorowicz, 1976).

A stack of these temperature logs is shown in Figure 4A. There are also some new logs performed in the Udryń PIG 1 borehole (2010). Major temperature logs in deep ( 2300 m) boreholes $(F, K, U)$ were performed after 10-14 days, while in shallow ( 300 m) boreholes from 1998 (W1,W2,W3) they were carried out 23 days after mud circulation in cased borehole. Only one temperature log from the borehole S (Sidorówka borehole, depth 520 m, performed in 2004; Šafanda et al., 2004) was run in fully stable thermal condition (after $>11$ months). Temperature measurements in the Udryn PIG 1 borehole drilled in 2010 (the borehole with permafrost discovered) were carried out three times under different thermal stability conditions. The first measurement (I) was carried out 58 hours after stopping the mud circulation, the second log (II) $234 \mathrm{~h}$ after, and the last log (III) 1800 $\mathrm{h}$ after, under nearly stable condition. The first two temperature logs were performed using a TEG-36 logger with continuous registration of temperature data. The last log was performed simultaneously by two HOBO U12-015 loggers (point by point registration mode with a $2 \mathrm{~m}$ step). Locations of boreholes with temperature profiles presented on Figure $4 \mathrm{~A}$ are shown on the Bouguer gravity anomaly map of the massif (Fig. 4B). Figure 5 shows a 3D (spatial) image of the Bouguer gravity anomaly of SAM and the location of all boreholes.

The temperature inversion with depth is observed in all temperature logs performed in boreholes drilled in the SAM area. In boreholes located outside the anorthosite intrusion, for example F (Filipów IG 1, see Fig. 4), the temperature inversion did not occur.

\section{CRYOGENIC ALTERATION OF GROUNDWATER}

The long existence of the deep-seated relict permafrost in northeastern Poland (Suwałki region) was inferred previously from hydrogeological studies. Thorough examination of hydrogeological results of the Krzemianka IGH 1 borehole (well $\mathrm{H}$ in Fig. 4B) suggested that cryogenic transformations were responsible for groundwater chemical composition in the SAM area. For the first time this phenomenon was observed by Michalski (1985) who hypothesized the presence of deep permafrost in the past. Later research carried out after many years fully confirmed this hypothesis.

Together with the decrease of subsurface temperature of groundwater, some of its chemical components precipitated during the freezing process. Calcite precipitated first from fresh cal- 

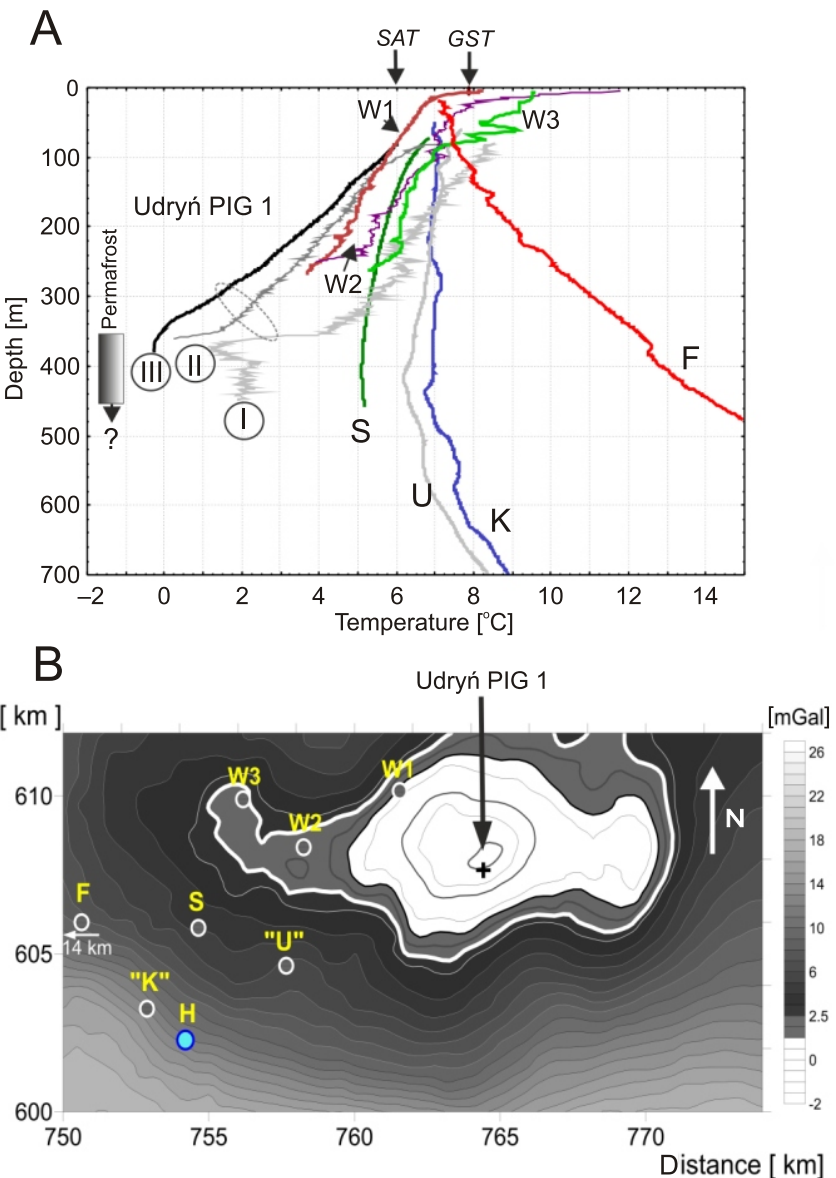

Fig. 4A - temperature logs in the new Udryń PIG 1 borehole and in old deep (F, K, U) and shallow (S, W1, W2, W3) boreholes from the SAM area; $B$ - location of boreholes with temperature logs are presented on the background of the Bouguer gravity anomaly

A: logs from Udryń PIG 1 were performed after different stabilization times (I - 58 h, II - 234 h, III - 1800 h); ground surface temperature (GST) and surface atmospheric temperature (SAT) for SAM is shown; temperature logs "K" and "U" are averaged for temperature logs respectively for all boreholes drilled for the Krzemianka $(K)$ and Udryń (U) ore deposits; B: the thick white contour line corresponds to the probable range of relict permafrost, white area - its most reliable occurrence area. $\mathrm{H}$ - hydrogeological borehole Krzemianka IGH 1, S - Sidorówka-1, W1- Wygorzel IG 21, W2 - Sumowo IG 30 W3 - Wygorzel IG 19 (after Szewczyk and Nawrocki, 2011, modified and supplemented)

cium bicarbonate waters at temperatures from $0^{\circ} \mathrm{C}$ to $-0.2^{\circ} \mathrm{C}$ whereas the other components remained in the solution. Therefore, the total mineralisation of groundwater (TDS) decreased and its chemical composition successively changed. These transformations are well visible in Figure 6.

Figure $6 \mathrm{~A}$ presents both earlier and new results of hydrogeological investigations performed in the SAM area. Figure 6B shows a Ca ion depth distribution in groundwater of this area. Figure 6C, D illustrates changes in the value of total mineralisation TDS (Fig. $6 \mathrm{C}$ ) and hydrochemical ion ratio $\mathrm{rNa} / \mathrm{rCl}$ for groundwater (Fig. 6D). At a depth of $\sim 620-630 \mathrm{~m}$ there is a notable change in the nature of groundwater, which determines the maximum depth range of cryogenic changes.

The results of hydrogeological investigations carried out in 2010 in the new borehole Udryń PIG 1 (with known presence of permafrost) confirmed earlier results. In the Cretaceous aquifer interval of $397-417 \mathrm{~m}$ there is $\mathrm{HCO}_{3}-\mathrm{Na}$ type groundwater characterized by very low mineralisation (TDS $\left.=0.48 \mathrm{gdm}^{-3}\right)$, which is typical for water altered by cryogenic processes (Michalski, 1985; Szewczyk et al., 2003; Honczaruk and Śliwiński, 2011).

All results generally confirm that the deep groundwater in the study area experienced transformations of cryogenic nature. The extremely low value of TDS, low value of $\mathrm{Ca}$ and $\mathrm{Mg}$ ions, and dominance of $\mathrm{Na}$ and $\mathrm{HCO}_{3}$ provide strong evidence of typical cryogenic alterations.

The water-to-ice phase transition, i.e. the water freezing and permafrost formation, can occur for the temperature values $T$ lower than $T_{L}\left(T<T_{L}\right)$. The thawing temperature of ice $\left(T_{L}\right)$, i.e. the freezing point, depends on pressure, lithology and total mineralization of groundwater in the pore space (Konrad and Seto, 1991). In clays, $T_{L}$ can be a few ${ }^{\circ} \mathrm{C}$ lower than in other rocks because the large specific surface of clays (i.e. capillarity and nature of soil particle surfaces) allows significant amounts of water to remain unfrozen (Waller et al., 2012).

Cryogenic changes in the groundwater chemistry, similar to those described above, are also observed in the Podlasie Depression (PD; Duchnowski and Michalski, 1987) located approximately $180 \mathrm{~km}$ S of SAM (see Fig. 3). The presence of cryogenically altered groundwater is observed here, even at a depth of up to $800 \mathrm{~m}$, i.e. to the top of crystalline basement. In contrast to the situation observed in the SAM area, this type of groundwater is found practically throughout the sedimentary cover (there is no old stagnant water with high mineralisation). Due to the lack of geothermal data, it cannot be determined whether the permafrost has preserved in this area to the present day.

\section{PETROPHYSICAL PARAMETERS OF ROCKS}

The processes of development and degradation of permafrost took place repeatedly in the Quaternary during glacial-interglacial cycles. Due to the larger volume of ice in relation to the volume of water, the total porosity of the rock increases, and thus its bulk density reduces.These processes highly influenced the physical properties of rocks, such as their porosity and density, and their structure.

The results of laboratory investigations of sedimentary rocks from the SAM area clearly show they are distinctively more porous and have lower density relative to the sedimentary rocks from other parts of the Polish Lowlands. Porosity values within a depth range of 200-600 m have anomalously high values in the range of $35-50 \%$, normally not found in sedimentary rocks, similarly to anomalously low bulk density values varying from 1.15 to $1.4 \mathrm{gcm}^{-3}$. Figure 7 presents the results of laboratory investigations of the dry bulk density for both sedimentary rocks of SAM (including the Udryn PIG 1 borehole) and the whole area of the Polish Lowlands. This phenomenon is especially observed in the $300-450 \mathrm{~m}$ interval, i.e. the interval of latest melting of permafrost.

A surprisingly large scale of this phenomenon has not been, as it seems, signaled in the literature. This may be primarily related to an extremely fast rate of permafrost degradation resulting from the abnormally high amplitude of temperature change between the period of LGM and the Holocene $\left(\Delta T=18^{\circ} \mathrm{C}\right)$, which is among the highest in the Northern Hemisphere (Demezhko et al., 2007). This phenomenon is perfectly confirmed by the results of laboratory petrophysical investigations of drill cores (Fig. 7), and by the results of well logging.

In short, the moment of ice appearance in the pore space, i.e. the start of permafrost formation, interrupts the natural process of compaction of the rocks, and even triggers the process 


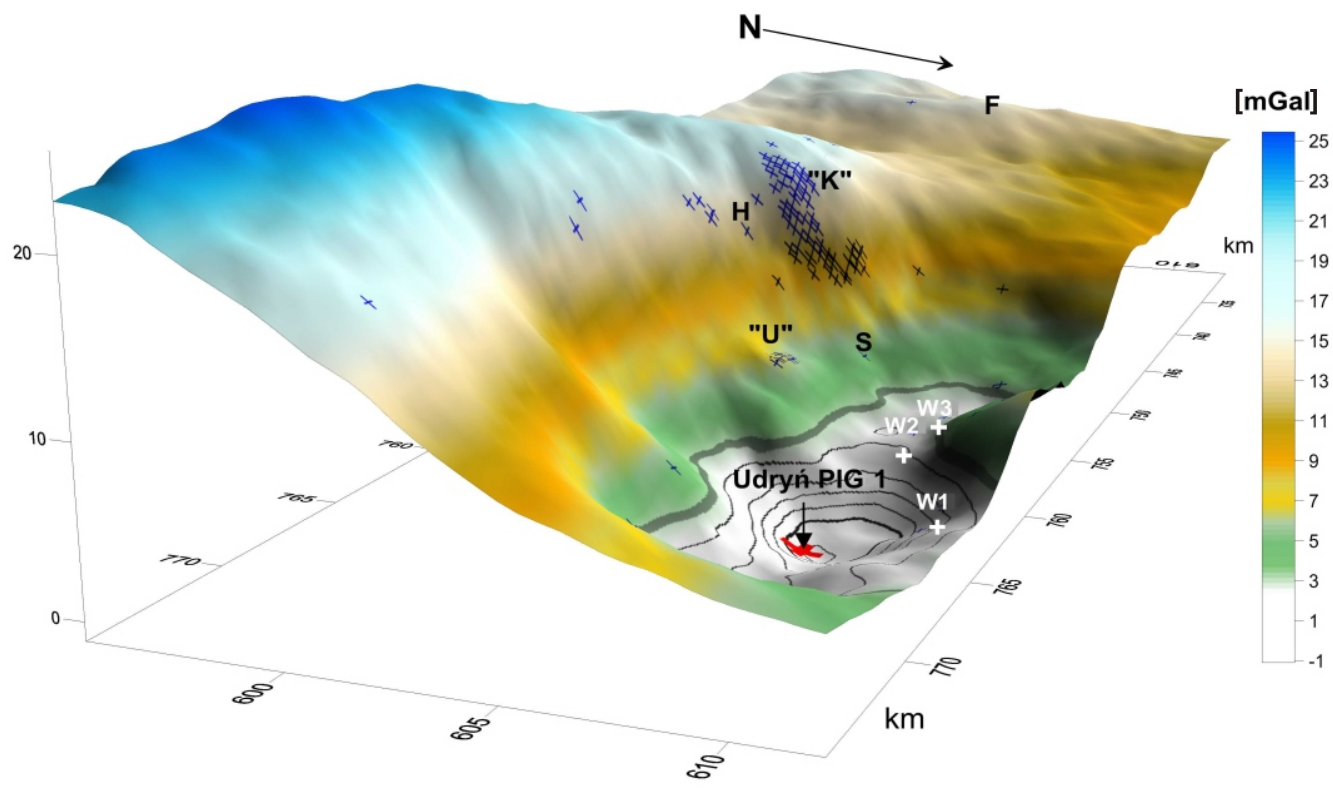

Fig. 5. 3D Bouguer gravity anomaly of the Suwałki Anorthosite Massif with the location of all boreholes (crosses)

"K" and "U" - group of boreholes for the Krzemianka and Udryń deposits, respectively; the white area corresponds to the probable range of contemporary existence of relict permafrost; other explanations as in Figure 4

of their decompaction, while the ice disappearance resumes the compaction process (but to another level of rock consolidation). This process is clearly visible in Figure 7, where the measure of degree of compaction of the rocks is their dry bulk density. The density inversion is the result of an earlier beginning of the process of recompaction for sediments that are closer to the Earth's surface (the process of melting of ice starts on the ground surface).

The observed Bouguer anomaly is associated with the very low density of sedimentary rocks of the overburden. Preliminary results of gravity modelling undoubtedly confirm this relationship (there is no other alternative explanation). In the shallowest parts of the profile (depths $<200 \mathrm{~m}$ ) we can observe progressive compactional reduction of the porosity and an increase of bulk density. A similar inversion of densities is observed in the sedimentary cover of the KAM area (Szewczyk, 2014).

\section{SURFACE VERSUS SUBSURFACE TEMPERATURES}

The terrestrial climate continuously fluctuates and even subsequent long glacial periods (90-100 ka do not mean the steady state of subsurface thermal regime to a depth of several kilometres. The Late Pleistocene climatic variations have had considerable effect on the present-day subsurface temperature regime. Former and recent climatic changes on the Earth can be recorded in the subsurface temperature profiles observed in deep boreholes. Effectively, reconstructions of a subsurface temperature profile $\left(T_{s}\right)$ as well as ground surface temperature history (GSTH) become more generalized with increasing time before the present day.

Along with the many common irregular changes in surface atmospheric temperature (SAT) and ground surface temperature (GST), observed in glacial periods (Petit et al., 1999; Stenni et al., 2010), there are respective increases or decreases of subsurface temperature $\left(T_{s}\right)$, with specific amplitudes and time shifts. Downward propagating thermal signals undergo period-dependent attenuation and spreading with depth. The time of arrival of a signal about the change of the surface temperature (SAT and GST) to a depth of 500-600 m for the conditions of SAM is $\sim 2000-3000$ years (referring to $\sim 50 \%$ of its amplitude).

Late Quaternary ice sheet/glaciations history of northern Eurasia, important for geothermal subsurface regime, was connected mainly with four glacial periods (1) the Late Saalian/Wartanian (>140 ka), (2) the Early Weichselian (100-80 ka), (3) the Middle Weichselian (60-50 ka), and (4) the Late Weichselian/LGM (25-15 ka; Svendsen et al., 2004). By the end of the Late Pleistocene, vast areas of the East European Plain belonged to the zone of low temperature continuous permafrost (Velichko et al., 2002). This zone extended 400-600 km S of the ice sheet boundary in Eastern Europe. Last results for the Pannonian Basin area (Hungary) very well confirm this hypothesis (Fábián et al., 2014).

Periglacial climate dominated in Poland during the Weichselian glaciations with very low mean annual temperature (SAT and GST) $<-10^{\circ} \mathrm{C}$ (Fig. 8), and low mean annual precipitation levels probably <100 mm/year (Mojski, 2005; Fábián et 

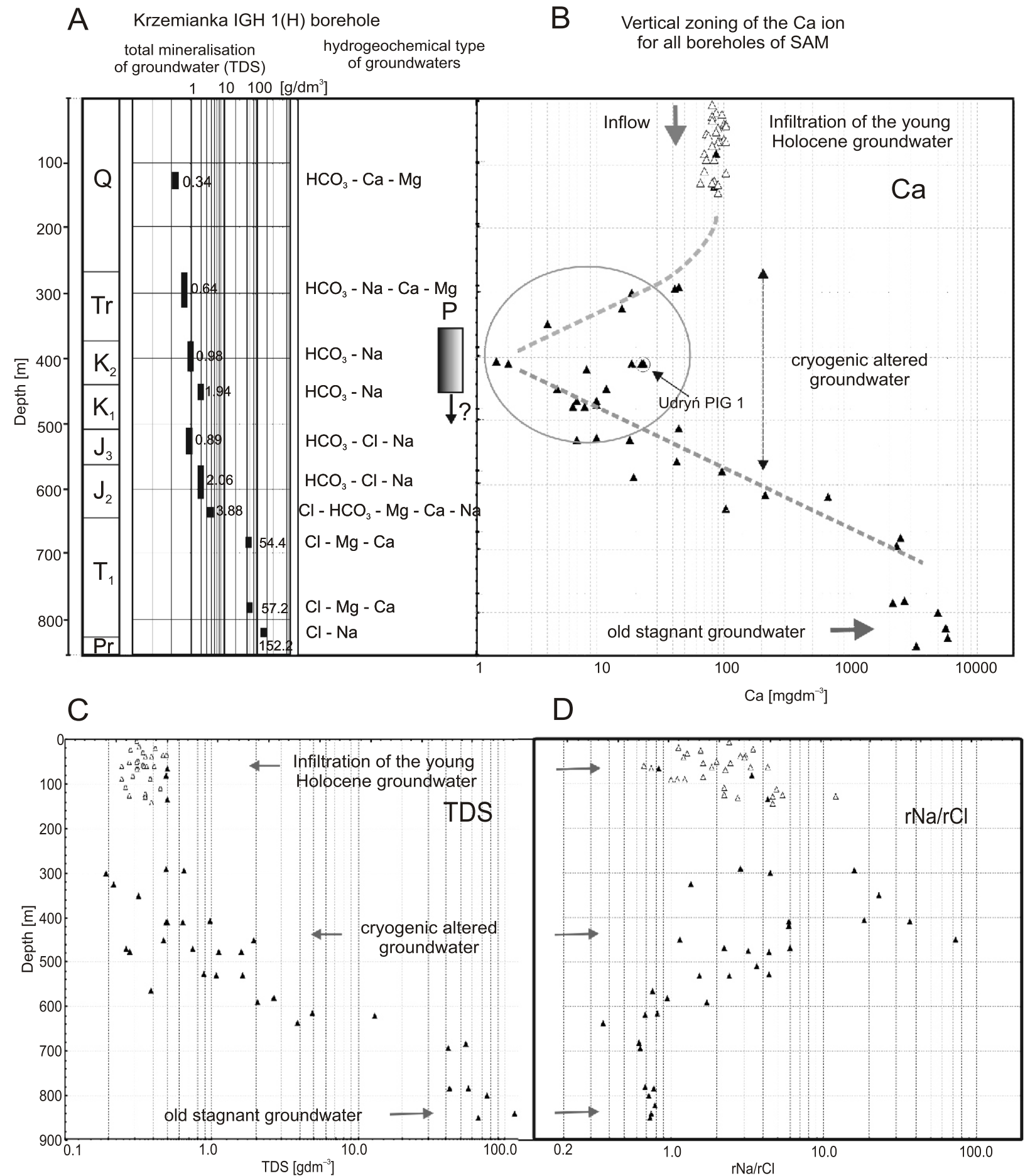

Fig. 6A, B - results of hydrogeochemical investigation of groundwater in Krzemianka IGH 1(H) (A), and the distribution of $\mathrm{Ca}$ ion against depth for the whole SAM area (B); C, D - the distribution of total mineralisation TDS (C) and ionic ratios for $\mathrm{rNa} / \mathrm{rCl}$ (D) against depth for the whole SAM area

A: P - relict permafrost in the Udryń PIG 1 borehole; B-D: black triangles - data from deep boreholes, white triangles - data from shallow hydrogeological wells

al., 2014). The only areas periodically occupied by a thin ice sheet cover (100-300 m thick) occurred in relatively short times in the very northern ends of Poland (Svendsen et al., 2004). The Polish Lowlands were practically free of ice sheets in Weichselian time.

Due of huge and thick Wartanian ice sheets and, furthermore, the relatively very warm Eemian climate vs. Holocene cli- mate, all older (>160 ka) permafrosts were probably completely degraded. Very impressive indirect evidences of huge thicknesses of the Wartanian ice sheet cover are 80-100 m thick postglacial sediments observed in the SAM area compared to approximately only $10 \mathrm{~m}$ of Weichselian postglacial sediments (Ber, 2000). 


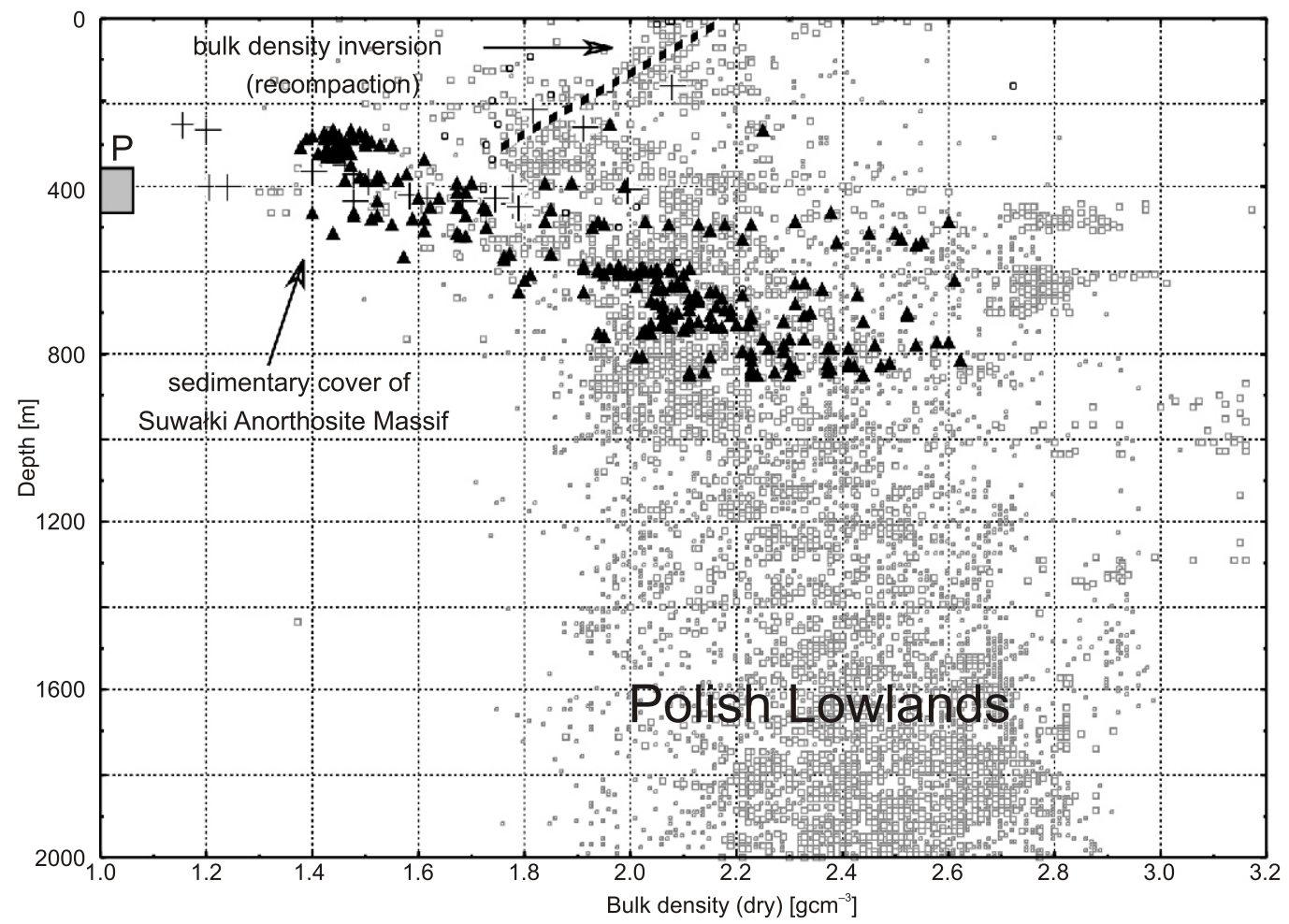

Fig. 7. Depth distribution of dry bulk density in the SAM area (black triangles) and in the Polish Lowlands (grey squares)

Crosses - results from the Udryń PIG 1 borehole, P - relict permafrost

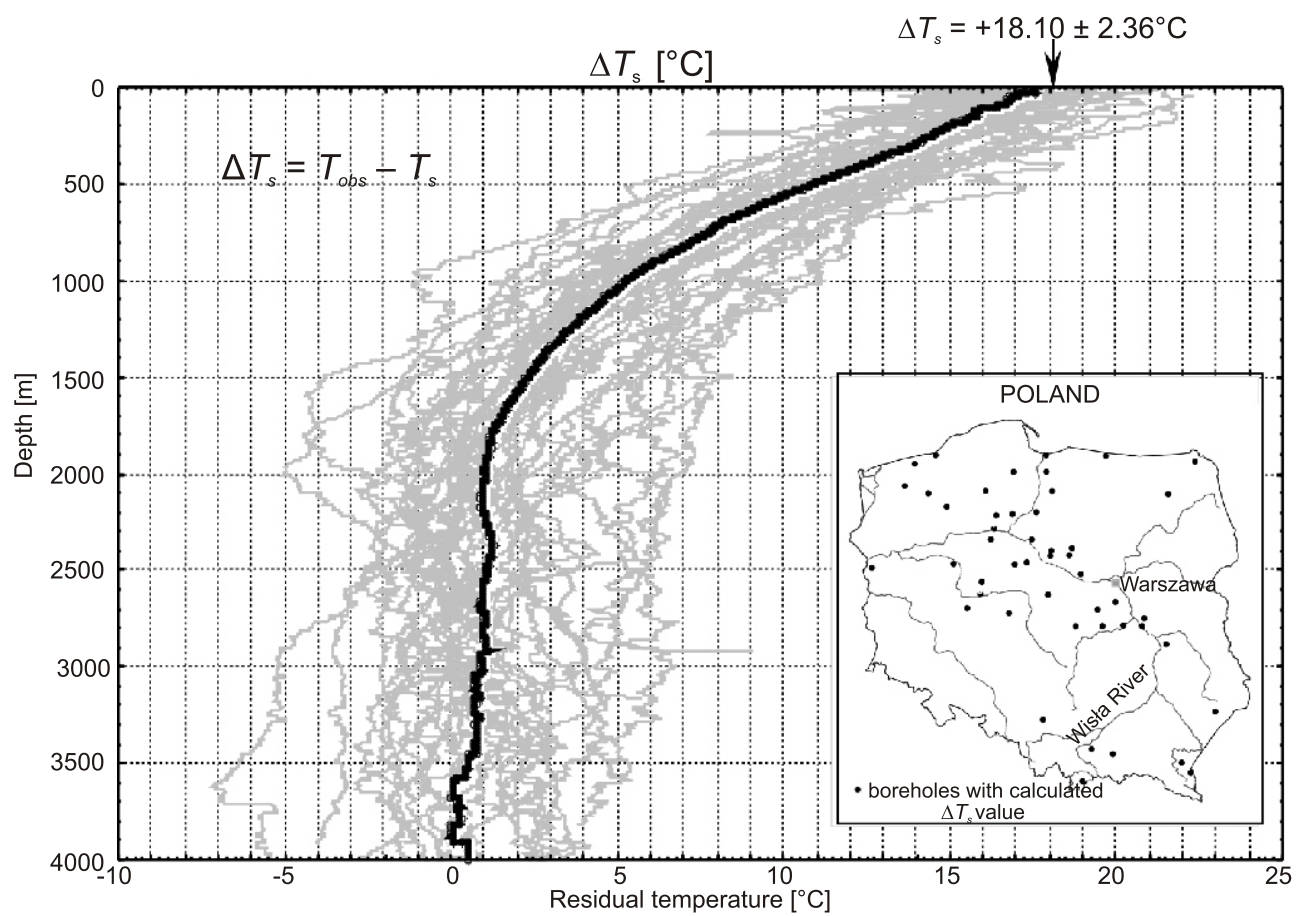

Fig. 8. Amplitudes of Weichselian/Holocene temperatures (residual temperatures) for 41 deep boreholes from the Polish Lowlands

Best fit line calculated by the methods of non-linear least squares is shown; $T_{s}$ - calculated effective quasi steady-state palaeotemperature profiles for the Weichselian, $T_{\text {obs }}$ - observed steady-state borehole temperature profiles for a representative group of 41 deep boreholes (see location map) 
The thermal regime of the shallow crust is determined mainly by the temperatures of the last two climate periods, i.e. of the Weichselian Glaciation and Holocene. The performed modelling has also shown that the effect of the present interglacial climate (beginning $\sim 14.3 \mathrm{ka} \mathrm{BP}$ ) has reached a depth of 1500-2000 m until now (Szewczyk, 2002, 2009). Beneath that depth, the geothermal conditions are still dominated by low temperatures of the last glaciations. The shallower part $(<2000 \mathrm{~m})$ is undergoing a transition from one quasi-stable state (glacial) to another (interglacial) state. Observed modern global warming disturbed this transition state in a depth range of $<100 \mathrm{~m}$.

Results of analysis based on both constructions of synthetic thermal logs $\left(T_{s}\right)$ and results of further modelling show (see Fig. 6) that the glaciation has left evident palaeoclimatic temperature signals in nearly all observed subsurface temperature profiles in deep boreholes from the Polish Lowlands (Szewczyk et al., 2005; Szewczyk and Gientka, 2009).

Some evidence based on analysis of present temperature logs from deep boreholes indicates that during the Weichselian Glaciation in Poland, the average annual ground surface temperature (GSTH) ranged from $\sim-8$ to $-12^{\circ} \mathrm{C}$ (Szewczyk, 2002; Šafanda et al., 2004; Szewczyk and Gientka, 2009). The mean annual temperature for the Suwałki meteo station (54.132 N, $22.950 \mathrm{E}, 180$ m.a.s.I.) in the period 1960-1980, i.e. before the main phase of contemporary global warming, is $+7.77^{\circ} \mathrm{C}$ for ground surface temperature (GST) and $+5.89^{\circ} \mathrm{C}$ for surface air temperature SAT (Fig. 4; Szewczyk, 2005). The station is located in a rural area outside the town of Suwałki approximately $13 \mathrm{~km}$ SW of the Udryń PIG 1 borehole. Between these two temperatures exist a linear relationship $G S T\left[{ }^{\circ} \mathrm{C}\right]=0.56 * S A T\left[{ }^{\circ} \mathrm{C}\right]+$ 4.41. The difference is due to the insulating effect of the winter snow cover. The global warming for the Suwałki station in the period 1980-2014 is $\sim \triangle S A T=+1.22^{\circ} \mathrm{C}$ (after Berkeley Earth Data, 2014).

The amplitude of mean ground surface temperature history (GSTH) between the Weichselian and Holocene for the Polish Lowlands, derived from deep borehole temperature logs and calculated by the author, amounts to $+18.1^{\circ} \mathrm{C} \pm 2.36^{\circ} \mathrm{C}$. Figure 8 shows calculated distribution of the temperature amplitude (reduced temperature) against depth between the Weichselian Glaciation and Holocene for 41 representative temperature profiles in deep boreholes from the Polish Lowlands (for the method of calculation see Szewczyk and Gientka, 2009). Due to poor temporal resolution of the temperature history during the Weichselian, the obtained GSTH as well as $\Delta T_{s}$ values should be regarded as an estimate of their average effective value. For comparison, new data from the Pannonian Basin (Hungary) indicates continuous permafrost may have been present between 22 and $16 \mathrm{ka}$, indicating mean annual temperatures $(G S T H)>15^{\circ} \mathrm{C}$ lower than at present in this region (Fábián et al., 2014).

Due to the preliminary stage of these calculations, it was assumed that the pores in rocks are completely filled with water into a liquid form. The obtained results indicate existence of very low palaeotemperatures during the last glacial period throughout Poland. Due to the general lack of temperature profile for the majority of deep boreholes for their upper parts $(<100 \mathrm{~m})$ the impact of contemporary climate change, i.e. global warming, was skipped in the above calculations. The result is in good agreement with the result obtained earlier by Šafanda et al. (2004) for the Udryń IG 8 borehole.

\section{PRESENT AND PAST THICKNESS OF PERMAFROST}

The Udryń PIG1 borehole did not reach the bottom of permafrost. It is an interesting question, however, what is the present thickness and what was the maximum permafrost palaeothickness during the final stage of the Last Glacial Maximum?

Present temperature data from the Udryń PIG 1 (depth $450 \mathrm{~m}$ ) do not provide any direct answer to this question. Such an evaluation would be possible only for boreholes of depths greater than the climate change depth range, i.e. $>2000 \mathrm{~m}$. The present-day temperature profile (especially for depths $>2000 \mathrm{~m}$ ) can be used as an important parameter for reconstruction of past subsurface thermal conditions (Fig. 9). Results of thermal modelling performed in the Udryn IG 8 borehole (Šafanda et al., 2004) show that the total palaeothickness of permafrost was $\sim 530 \mathrm{~m}$; new results with a new more accurate determination of $T_{L}$ value show $\sim 520 \mathrm{~m}$. The hydrogeochemical evidences show (Fig. 6) that the mean palaeothickness of permafrost $\left(\mathrm{PF}_{\mathrm{HYD}}\right)$ for the marginal part of SAM comprising the boreholes "U", "K" and H was 620-630 m.

Not only temperature values (SAT and GST) but also depth distribution of subsurface temperature related to terrestrial heat-flow density (HFD) and rock parameters are the contributing factors determining permafrost development and its preservation. The thermal regime of sediments in permafrost areas is significantly characterized by non-steady conditions for the entire period of permafrost existence. The main critical factor in thermal modelling is knowledge of the distribution of thermal conductivity $(T C)$ in situ conditions against depth. A geophysical method of TC calculation was performed for the whole Udryn IG 8 profile in depth ranges totaling 2300 m (Szewczyk, 2002). The state of water in the pore space can significantly modify the thermal conductivity of rocks; such influence is further complicated by the volume fraction of ice and liquid water, being itself temperature-dependent. Thermal conductivity of pure water and ice differs significantly: $T C$ _water $=0.59 \mathrm{~W} / \mathrm{m}^{\circ} \mathrm{K} ; T C$ ice $=$ $2.1 \mathrm{~W} / \mathrm{m}^{\circ} \mathrm{K}$, respectively. Because permafrost frequently contains water, either as a liquid or as a solid (ice), it is important to differentiate between its temperature and state. Significantly, the thermal boundaries between frozen and unfrozen rocks can differ by a few degrees Celsius, because the temperature at which ice starts to nucleate in porous media can be lowered by dissolved salts and pressure melting (Waller et al., 2012).

The thawing temperature of the ice liquids $\left(T_{L}\right)$ depends on pressure, lithology, and mineralization of groundwater in the pore space (Konrad and Seto, 1991). The water-to-ice phase transition, i.e. creating permafrost, can occur only for temperatures $T<T_{L}$. This is a critical factor impeding to perform a realistic thermal modelling of permafrost (Galushkin, 1997; Šafanada et al., 2004). In practice, permafrost thickness is complicated by additional factors, most notably the presence of ice and water close to their phase transition temperature. In addition, the high heat capacity of water and the release of latent heat on freezing can substantially slow the rate of permafrost aggradation. The scientific understanding of these effects is very low (Waller et al., 2012).

For the studied marginal part of SAM, comprising the boreholes "U", "K", H and S (Fig. 4) with available hydrochemical data, the permafrost completely disappeared before $\sim 4$ ka (Šafanada et al., 2004; Mottaghy and Rath, 2006), but the cryo- 


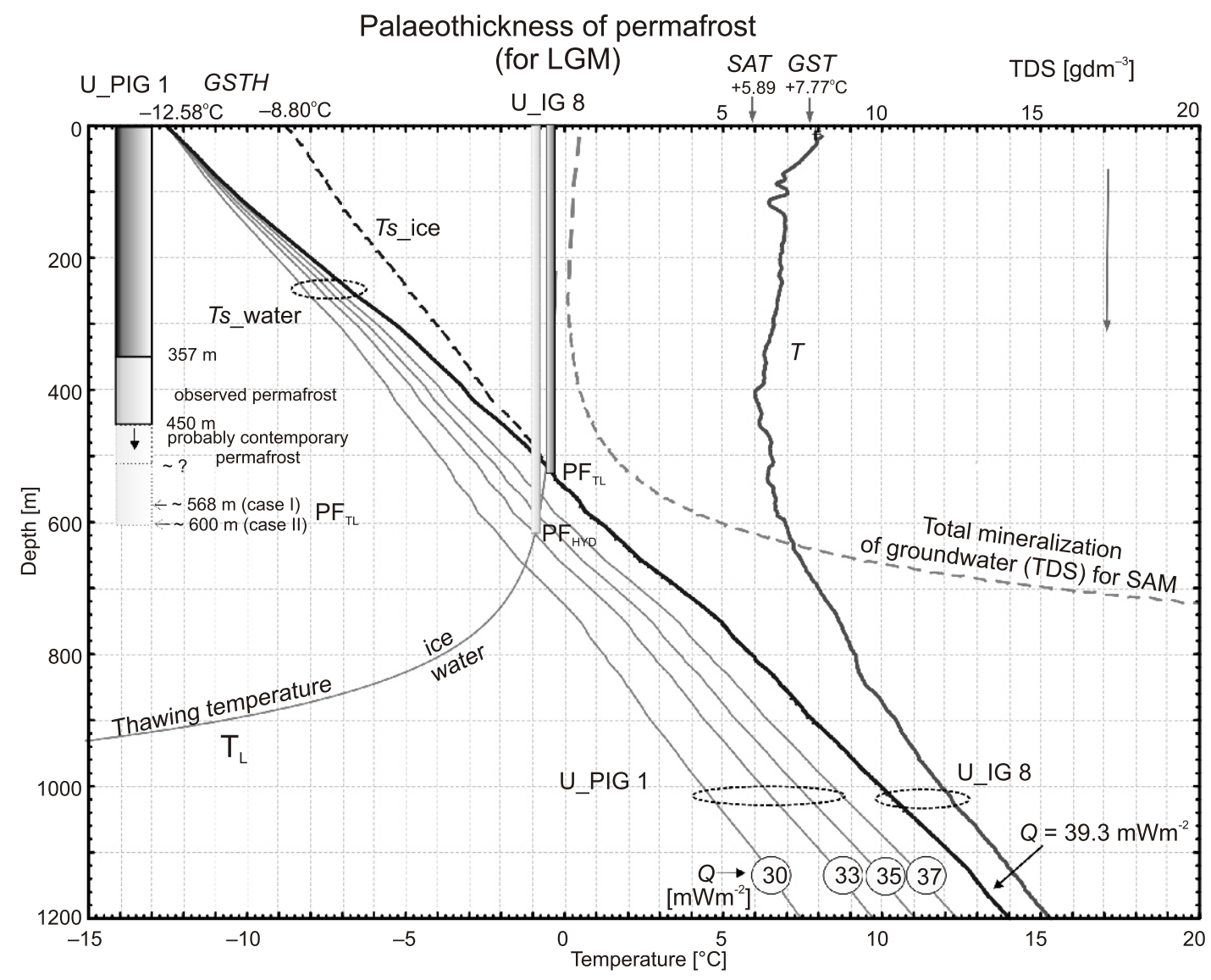

Fig. 9. Results of geothermal modelling of the permafrost palaeothickness in the Udryn IG 8 and Udryń PGI 1 boreholes

GSTH - calculated ground surface glacial temperature, $T$ - observed temperature, $T_{s}-$ calculated palaeotemperatures for the ice (Ts_ice) and water (Ts_water), $Q$ - heat flow density

genic anomalies have remained. Thus, traces of cryogenic transformation can be treated as information about the maximum palaeothickness of permafrost $\left(\mathrm{PF}_{\mathrm{HYD}}\right)$, i.e. the maximum depth of cryogenic alteration.

In the case of ground surface and subsurface temperature reduction, after reaching the permafrost base, the thermal signal would initiate a cryogenic process of a change in the chemical composition of groundwater under the permafrost. The first result was the relatively rapid precipitation of calcite, followed by the water-ice phase transformation process. In the opposite case, i.e. an increase in subsurface temperature, the previously formed chemical composition of the groundwater did not change, whereas the ice, which formed earlier in the pore space, melted. Permafrost disappears, but the hydrochemical anomaly remains for a long time. Hence, always $\mathrm{PF}_{\mathrm{HYD}}>\mathrm{PF}_{\mathrm{TL}}$.

Due to the preliminary stage of these modellings, it was assumed that there were only two extreme forms of existence of water in the pore space, i.e. the pores completely filled up with either water or ice. Figure 9 presents the results of modelling of permafrost thickness in the Udryn IG 8 borehole (total depth $2300 \mathrm{~m}$ ). The temperature $T_{L}$ (thawing temperature), regarded as a function of depth, was calculated based on the depth-dependent distribution of the total value of TDS and natural hydrostatic pressure in the SAM area.

The depth in the formula $T_{L}=f($ depth) is a natural maximum depth of permafrost formation in the SAM area. The HFD value, as well as the palaeotemperature profile $\left(T_{s}\right)$, was calculated assuming that the pore space is filled with either water or ice.
The calculated present-day undisturbed heat flow density in the Udryń IG 8 borehole is $39.3 \mathrm{mWm}^{2}$, and the effective ground surface temperature for the Weichselian glaciations GSTH is $-12.58^{\circ} \mathrm{C}$ for $T C \_$water and $-8.80^{\circ} \mathrm{C}$ for TC_ice. The actual value of GSTH is between the values of the two temperatures. The results of GSTH modelling depend strongly on the values of petrophysical parameters of frozen and unfrozen rocks.

The base of palaeopermafrost can be determined by intersection of the calculated palaeotemperature profile $\left(T_{s}\right)$ with the temperature $T_{L}$. The calculated effective palaeothickness of permafrost for the Udryń IG 8 borehole is $\sim 520 \mathrm{~m}$ (Fig. 9). For the considered case, the thicknesses are $\mathrm{PF}_{\mathrm{HYD}}=620 \mathrm{~m}$, and $\mathrm{PF}_{\mathrm{TL}}=520 \mathrm{~m}$, respectively. At the moment, the author does not know alternative explanations of the facts presented in Figures 4 and 8.

Due to the insufficient total depth of the Udryń PIG 1 borehole (450 m), determination of its HFD value has not been possible on the basis of the above-described method. It is possible to estimate this parameter based on the analysis of the relationship between the temperature profiles and Bouguer anomalies. This approach is based on the assumption that the observed temperature $T(z)$, as well as calculated $T_{s}(z)$ below $1500-2000 \mathrm{~m}$, is close to the steady state corresponding to the long-term surface temperature (GSTH), and unaffected by the latent heat effect.

The sedimentary overburden of SAM forms a very clearly ordered, stable, plane-parallel rock body with laterally stable petrophysical properties. We assume that heat is transported only by vertical conduction (1D): 


$$
T_{s}(z)=G S T H+Q \int_{0}^{z} \frac{d z}{T C(z)}-M(z)
$$

where: GSTH - effective average ground subsurface palaeotemperature for Weichselian glaciations; $Q-$ heat flow density; $T C(z)$ - thermal conductivity coefficient at depth $z, M(z)$ - radiogenic component of heat flow.

The values GSTH and TC(z) in equation [1] are very stable and nearly constant in almost the whole SAM area.

Radiogenic heat value $M(z)$ for the basement rocks in nearly the whole SAM area is very low and spatially stable (after results of gamma ray logs) and has no relevant effects on the subsurface thermal state. After Majorowicz (1984), its value is $\sim 0.2 \mu \mathrm{Wm}^{-3}$ (for anorthosites). For comparison, the radiogenic heat value of granitoids, i.e. typical and dominant crystalline basement rocks in NE Poland, which compose the surroundings of SAM, is significantly higher and varies from 1.7 to $3.9 \mu \mathrm{Wm}^{-3}$. It is likely that granitoids of the crystalline basement in the Filipów IG 1 borehole also show such values (see Fig. 4, borehole $F$ ). The heat flux value in this borehole, $Q=$ $71.7 \mu \mathrm{Wm}^{-2}$, is nearly twice higher than in the SAM area.

The $T_{s}(z)$ palaeotemperature profile for steady-state equilibrium condition $(Q(z)=$ const $)$ is a function of the value of heat flow $Q$ and the value of thermal conductivity coefficient $T C(z)$. Such conditions existed approximately at the end of the last glacial period (LGM; Szewczyk and Gientka, 2009).

For depths greater than the depth of the zone of climate change impact (i.e. $>1500-2000 \mathrm{~m}$ ) in the SAM area, a temperature difference $\Delta T_{s}$ between any two profiles for the same depth is linearly dependent on the difference of the heat flow values $\Delta Q$ in these profiles:

$$
\Delta T_{s}=\Delta Q \int_{0}^{z} \frac{d z}{T C(z)}
$$

Figure 9 shows the results of modelling of the permafrost palaeothickness for both the Udryń PIG 1 borehole and the Udryń IG 8 borehole, the only borehole with the fully calculated $T C(z)$ profile.

The variability in the depth of TDS for the whole SAM area, the calculated phase transition temperature $T_{L}(z)$, and a set of palaeotemperature data $T_{s}(z)$ calculated for different hypothetical values of heat flow are also presented. The intersection of $T_{s}(z)$ with $T_{L}(z)$ determines the palaeothickness $\mathrm{FT}_{\mathrm{TL}}$. For comparison, the $T_{s}(z)$ curve and the palaeothickness calculated for the reference Udryń IG 8 borehole are presented.

The steady-state temperature $T_{s}$ at a depth of $2000 \mathrm{~m}$ averaged for the whole group of wells " $U$ " and " $K$ " (see Figure 4B) is $T_{2000 \mathrm{U}}=31.8^{\circ} \mathrm{C}$ (“U”) and $T_{2000 \mathrm{~K}}=34.7^{\circ} \mathrm{C}$ ("K"). For obvious reasons the temperature decreases towards the centre of the gravimetric anomaly (Fig. 4B). The greatest decrease in temperature $T_{s}$ and heat flux $Q$ should be observed in a direction normal to the isolines of the Bouguer anomaly. This is well confirmed by the observed increase in the depth of temperature inversion, which occurs at the following depths: $440 \mathrm{~m}$ (13.09 mGal) in "K", $418 \mathrm{~m}$ (6.36 mGal) in "U", and $406 \mathrm{~m}$ $(4.62 \mathrm{mGal}$ ) in $\mathrm{S}$ (in parentheses the value of Bouguer anomaly). The results of modelling performed earlier for the Udryń IG 8 borehole confirm the occurrence of this phenomenon (Šafanda et al., 2004; Mottaghy and Rath, 2006). The greater depth of the inversion means that the permafrost disappeared earlier.
On the assumption that the change of temperature (and heat flux) is linearly dependent on the increase in the Bouguer anomaly, it can be proved that the value $T_{2000}=31.8-3.1=$ $28.7^{\circ} \mathrm{C}$ for the Udryn PIG 1 borehole. That corresponds, according to the formula [2], to the flux $Q=37.02 \mathrm{mWm}^{-2}$ and the effective palaeothickness of $\sim 568 \mathrm{~m}$ ( $\mathrm{PF}_{\mathrm{TL}}-$ case I - see Fig. 9). If we assume another criterion, based e.g. on the distance between the "K", "U" and Udryń PIG 1 boreholes (located approximately on one line), the temperature $T_{s}=26.1^{\circ} \mathrm{C}, Q=$ $34.8 \mathrm{mWm}^{-2}$, and the permafrost palaeothickness is $\sim 600 \mathrm{~m}$ $\left(\mathrm{PF}_{\mathrm{TL}}\right.$ - case II).

Due to the need to adopt assumptions that are impossible to verify, the above-described considerations allow, at the current stage of research, for treating these results as a testing hypothesis. However, they allow obtaining approximate knowledge on the range of the maximum palaeothickness of the analysed relict permafrost. A very costly alternative for the direct acquisition of data on the depth distribution of temperature (and heat flow) and on the permafrost palaeothickness in the centre of the gravimetric anomaly would be to drill a deep borehole to a depth exceeding 2200-2500 m. In order to acquire knowledge on the contemporary thickness of the permafrost, we should deepen the existing Udryń PIG 1 borehole to a depth of $\sim 580-600 \mathrm{~m}$.

The presence of rocks with anomalously high total porosity (40-50 vol.\%), particularly in case of their pore space filled with water, affects their extremely low thermal conductivity (Szewczyk, 2002; Szewczyk and Gientka, 2009). It leads to significant decreasing of rate transfer of heat energy. This is the case during both the formation and disappearance of permafrost. These high porosity rocks act as an insulating layer; they slow down both processes.

If the climatic temperature increases in a profile with a temperature of $T>T_{L}$, permafrost (ice) decays. Traces of cryogenic transformation can be treated as information about the maximum palaeothickness of permafrost $\left(\mathrm{PF}_{\mathrm{HYD}}\right)$, while the thickness of palaeopermafrost determined on the basis of the profile palaeotemperature $\left(T_{S}=T_{L}\right)$ is the effective average palaeothickness of permafrost $P F_{T L}$. In all cases $P F_{H Y D}>=P F_{T L}$.

The presence of ice in the pore space of sedimentary rocks of the SAM overburden significantly increases their thermal conductivity. It affects the acceleration of heat propagation, i.e. reduces the time of its arrival to the base of permafrost. This is especially important in glacial time. Cryogenic transformation of groundwater, associated even with relatively short-term changes of temperature of aquifers, affects their chemical composition for a long time. It is worth noting that for the value of palaeotemperature $T_{S}=T_{L}$, i.e. for the pore space completely filled by water, it determines the base of permafrost regardless of the water/ice ratio in the pore space of the overburden.

Preliminary results of geothermal analysis indicate that the present-day maximum depth of the permafrost base should be probably located at $\sim 470-500 \mathrm{~m}$, and the maximum permafrost palaeothickness in the centre of SAM at the end of the LGM period was up to $\sim 570-600 \mathrm{~m}$ (see Fig. 9). It is worth mentioning that, for the whole Polish Lowlands, the calculated effective palaeothickness of permafrost for thermal data from 227 deep boreholes was estimated at $190 \pm 53 \mathrm{~m}$ (Szewczyk et al., 2007). This result is very similar to the assessment obtained by Velichko et al. (2002) for this part of Central Europe.

The permafrost palaeothickness is a function of both climate temperature (SAT and GST) and the value of terrestrial heat flow density $(Q)$ accompanied by the thermal conductivity $T C(z)$ profile. Spatial and temporal variability of climate is a monotonic function of relatively "mild" variation. In contrast, 
spatial distribution of the heat flow is associated mainly with the local geological structure, showing significantly greater spatial variability (cf. Fig. 3 vs. Fig. 8). The diversity of the permafrost thickness determines, therefore, mainly the value of $Q$.

The recent attempts to evaluate the thickness of contemporary permafrost in the Northern Hemisphere (Kitover et al., 2013, 2015), or its palaeothickness (Kitover et al., 2016), based on geothermal data, and the noticeable impasse in these studies have their origin primarily in inadequate knowledge about terrestrial heat flow and, in particular, in the non-stationary nature of the flow in the shallow lithosphere $(<1500-2000 \mathrm{~m})$. However, these issues are not included in the studies (see Szewczyk and Gientka, 2009).

The method of Kitover et al. (2013, 2015, 2016) employs questionable hypotheses about all these parameters required to estimate the permafrost thickness, i.e. the values of $Q, G S T H$ and $T C(z)$. The method of the calculation of the permafrost thickness presented in the article would not need any assumptions. Moreover, the results obtained are a source of independent knowledge about these parameters. The case of occurrence of relict permafrost in the SAM area, presented in this article, is and will be in the future an important subject of research for a better understanding of the nature of such objects.

\section{DEVOLOPMENT AND PRESERVATION OF DEEP PERMAFROST}

A negative gravity anomaly observed over the SAM, as well as over the larger KAM (Fig. 4), was up to now difficult to explain (Cieśla and Wybraniec, 1998). The presence of permafrost may provide a proper explanation of the genesis of this anomaly. The Bouguer anomaly is in both cases associated with the very low bulk density of rocks of the sedimentary cover (Szewczyk, 2014).

Preliminary results of gravity modelling seem to confirm such a relationship, and there is no alternative explanation of this phenomenon. The heat flow density anomaly is proportional to the value of the basal heat flow and thus to the effective maximum palaeothickness of permafrost. The anomaly values can be partly influenced by both the present-day permafrost thickness (with ice) and the observed process of density recompaction in its near-surface part (Fig. 5).

Considerations based on the analysis of gravimetric, geothermal, petrophysical and hydrogeological data allow enunciate the following conclusions:

1. A clear conformity of gravimetric anomaly (Figs. 4 and 5) with the spatial distribution of the negative temperature gradient can provide confirmation of the thesis about the relationship between these parameters. The gravimetric anomaly may be a direct result of both currently existing and past permafrost.

2. The anomalous low bulk density of rocks observed in the zone of present and past permafrost may be the result of repeated processes of freezing and thawing of water in the pore space during successive climatic cooling and warming

3. These processes could lead to the modification of the structure of rocks occurring in the area affected by permafrost and consequently to the increase of the pore space volume. It was most marked in zones of the latest disappearance of permafrost, and especially in areas of its contemporary presence. Above them, there was probably a reverse process, i.e. the gradual recompaction of rocks leading to the decrease of the pore space and the increase of the bulk density of rocks.
4. The Bouguer anomaly is a result of the following cause-and-effect sequence: low climatic temperature \& low heat flow $\rightarrow$ permafrost formation \& degradation $\rightarrow$ bulk density decrease $\rightarrow$ negative gravimetric anomaly.

5. At the present stage of the study in the SAM area, the permafrost may be determined mainly from the Bouguer anomaly The thick white contour line shown in Figures $4 \mathrm{~B}$ and 5 marks a probable presence of relict permafrost, the white area - its reliable occurrence. Analysis of geophysical and hydrogeological data indicates the possibility of preserving the permafrost in the central part of SAM probably over an area of nearly $50 \mathrm{~km}^{2}$, with the present-day maximum thickness of 110 to $150 \mathrm{~m}$.

6 . The formation of the deep permafrost, beyond the obvious influence of climatic temperature factor, was the result of the existence of a very low heat flow value as well as of a very porous, water-saturated sedimentary cover. The whole profile of sedimentary rocks has the anomalously low value of thermal conductivity and the high heat capacity of water in the pore space (latent heat). The overburden cover, acting as an insulating layer, initially delaying the formation of permafrost, and then, during the Holocene in the same way delaying the permafrost warming, acted as a protection against fast permafrost degradation.

\section{COMPARISON OF THE PERMAFROSTS FROM SAM AND URENGOY}

Northern and Central Europe were the areas exposed to a harsh periglacial climate at the forefront of the Fennoscandian ice sheets. Deep borehole temperature logs acquired in equilibrium conditions reveal that the heat flow gradually increases with depth, reaching the values undisturbed by the glacial cycles. The SAM area was located in the periglacial climate zone for the most of Late Weichselian time, for most of the time outside of the Fennoscandian ice sheet, but still close to it.

The difference in the temperature between the Weichselian Glaciation and Holocene in NE Poland is much greater than that, e.g., in the Urengoy region located in the West Siberian Basin, with numerous deep boreholes and well-recognized processes of the formation and evolution of deep permafrost (Galushkin, 1997; Ananjeva et al., 2003). The advanced numerical geothermal modelling of permafrost evolution in the well $411\left(66^{\circ} \mathrm{N}\right.$ $77^{\circ} \mathrm{E}$ ) in this area was presented by Galushkin (1997).

The Weichselian/Holocene temperature amplitudes are +18 and $+13^{\circ} \mathrm{C}$, respectively - see Figure 10 (Demezhko et al., 2007). As a consequence of this, the permafrost palaeothickness in the SAM area is at least $540 \mathrm{~m}$, and increases towards the anomaly centre probably even to $600 \mathrm{~m}$, compared with $\sim 450 \mathrm{~m}$ in Urengoy (at $13 \mathrm{ka} \mathrm{BP}$ ).

In the Urengoy area (still within GST $<0^{\circ} \mathrm{C}$; see Romanovsky et al., 2010), permafrost disappears exclusively from its bottom part with a slow rate $(\sim 6 \mathrm{~m} / \mathrm{ka})$. In the SAM area, with $G S T=$ $+7.77^{\circ} \mathrm{C}$, melting occurs both from the top and from the base, with a considerably higher rate of $35 \mathrm{~m} / \mathrm{ka}$ at the top and unknown rate at the base. Figure 10 schematically shows this situation.

The depth of the top of the relict permafrost $(357 \mathrm{~m})$ reported in the Udryn PIG 1 borehole is probably one of the greatest depths of this phenomenon observed in the world until now (Ananjeva et al., 2003). 


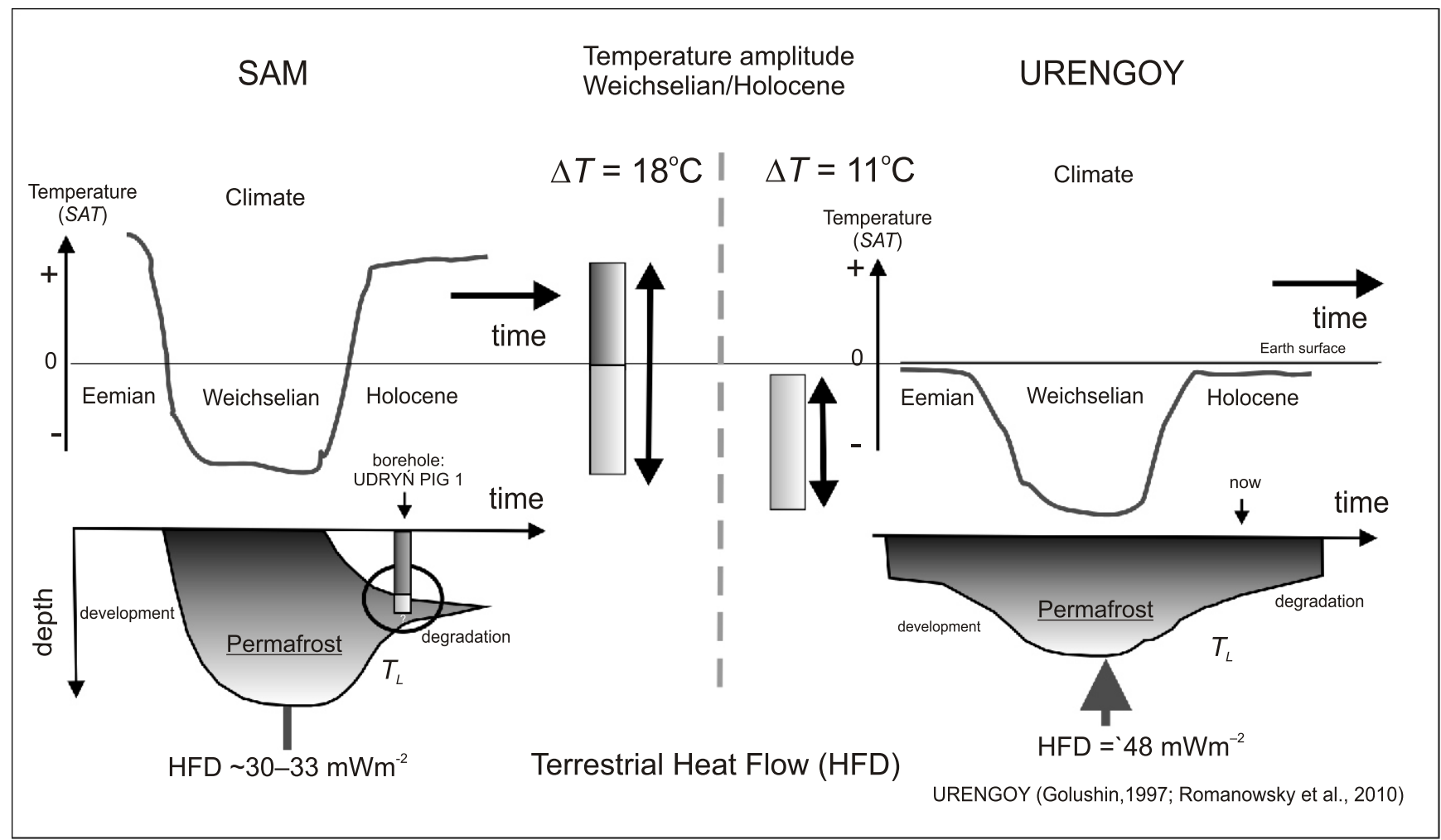

Fig. 10. Schematic comparison of the existence of permafrost during the Weichselian Glaciation and the Holocene for SAM and Urengoy (West Siberian Basin)

\section{CONCLUSIONS}

1. The Udryń PIG 1 research borehole drilled in northeastern Poland revealed a permafrost layer located below a depth of $357 \mathrm{~m}$, which extends over $\sim 50 \mathrm{~km}^{2}$. The base of the permafrost has not been reached at $450 \mathrm{~m}$ depth, so its total thickness remains unknown. However, first calculations indicate that its present maximum thickness may attain 110 to $150 \mathrm{~m}$, with the permafrost base at $\sim 470-500 \mathrm{~m}$.

2. The permafrost remains in the ice-water transition phase at a temperature of $-0.245^{\circ} \mathrm{C}$, corresponding to the thermodynamic conditions of its occurrence. It means that this permafrost layer can partly remain unfrozen, i.e. in the so-called "cryotic state". All the aquifers of SAM at a depth range of $\sim 300-600 \mathrm{~m}$ are filled by low-mineralised groundwater of $\mathrm{HCO}_{3}-\mathrm{Na}$ type with exceptionally low levels of $\mathrm{Ca}$ ion values typical for waters altered by cryogenic processes.

3. The deep relict permafrost discovered in the sedimentary cover of SAM in 2010 confirms that such a phenomenon has probably still remained undetected in relatively large areas of Eastern and Central Europe, where geophysical conditions are similar, and possibly in other areas of the world.

4. It is very likely that so-far undetected similar layers of deep relict permafrost exist in Poland also in other parts of the Precambrian Platform, i.e. in the KAM and PD areas.

5. The case of the Suwałki Anorthosite Massif is unique and important, not only as the geological object itself - further research may substantially change our knowledge on geological, hydrogeological, petrophysical, geophysical and climate processes that occurred in past times on a global scale.
6. The gravimetric anomaly is probably the direct result of the occurrence of both existing and past permafrost. Its maximum palaeothickness in the centre of the SAM anomaly for the final stage of the Last Glacial Maximum period is up to $\sim 560-600 \mathrm{~m}$. The contemporary area of the permafrost occurrence is probably $\sim 50 \mathrm{~km}^{2}$ based on gravimetric data.

7. Current global climate change and the corresponding change in permafrost extent need not only knowledge of present-day permafrost. The method of permafrost palaeothickness calculation, presented in the article, can be useful in these studies.

Acknowledgements. This study was supported by the Ministry of the Environment of Poland from the sources of the National Fund for Environmental Protection and Water Management. The author would like to express his thanks to Prof. G. Pieńkowski from the Polish Geological Institute for valuable remarks that helped to finally shape this paper, and to Dr. J. Šafanda from the Academy of Sciences of the Czech Republic for numerous constructive and inspiring discussions on subsurface geothermal processes and their relationship with the palaeoclimate questions. Thanks are due to Dr. W. Dobiński from the University of Silesia (in Katowice) and Anonymous Reviewer for numerous constructive comments that helped greatly to improve the final version of manuscript. Special thanks for the GQ editorial team for suggestions and comments. Thanks are due to Dr. J. Majorowicz from the University North Dakota for his useful support during the early phase of the project development. 


\section{REFERENCES}

Ananjeva (Malkova), G.V., Melnikov, E.S., Ponomareva, O.E., 2003. Relict permafrost in the central part of Western Siberia. Earth Cryosphere Institute, Siberian Division, Russian Academy of Sciences: Russia, Moscow. In: Permafrost (eds. M. Phillips, S.M. Springman and L.U. Arenson): 5-8. Swets \& Zeitlinger, Lisse, ISBN 9058095827.

Berkelay Earth Data, 2014. http://berkeleyearth.org/

Ber, A., 2000. Pleistocene of north-eastern Poland and neighboring areas against crystalline and sedimentary basement (in Polish with English summary). Prace Państwowego Instytutu Geologicznego, 170: 1-89.

Cieśla, E., Wybraniec, S., 1998. Geophysical studies of Suwałki Anorthosite Massif. Prace Państwowego Instytutu Geologicznego, 161: 27-38.

Demezhko, D.Y., Ryvkin, D.G., Outkin, V.I., Duchkov, A.D., Balobaev, V.T., 2007. Spatial distribution of Pleistocene/Holocene warming amplitudes in Northern Eurasia inferred from geothermal data. Climate of the Past, 3: 559-568.

Duchnowski, Z., Michalski, T., 1987. Chemistry of groundwater in the northern Podlaski Basin at the background of Pleistocene evolution (in Polish with English summary). Przegląd Geologiczny, 35: 138-143.

Fábián, S.Á., Kovács, J., Varga, G., Sipos, G., Horváth, Z., Thamó-Bozsó, E., Tóth, G., 2014. Distribution of relict permafrost features in the Pannonian Basin, Hungary. Boreas, 43 722-732.

Galushkin, Yu., 1997. Numerical simulation of permafrost evolution as a part of sedimentary basin modelling: permafrost in the Pliocene-Holocene climate history of the Urengoy field in the West Siberian basin. Canadian Journal of Earth Science, 34 935-948.

Honczaruk, M., Śliwiński, Ł., 2011. Results of hydrogeological research of the deep permafrost zone in the Udryń PIG-1 borehole (in Polish with English summary). Biuletyn Państwowego Instytutu Geologicznego, 445: 203-216.

Kitover, D.C., van Balen, R.T., Roche, D.M., Vandenberghe, J., Renssen, H., 2013. New estimates of permafrost evolution during the last $21 \mathrm{k}$ years in Eurasia using numerical modelling Permafrost and Periglacial Processes, 24: 286-303.

Kitover, D.C., van Balen, R.T., Roche, D.M., Vandenberghe, J., Renssen, H., 2015. Advancement toward coupling of the VAMPER permafrost model within the Earth system model iLOVECLIM (version 1.0): description and validation. Geoscientific Model Development, 8: 1445-1460.

Kitover, D.C., van Balen, RT,. Vandenberghe, T,. Roche, DM and Renssen, H., 2016. LGM permafrost thickness and extent in the Northern Hemisphere derived from the Earth System Model iLOVECLIM. Permafrost and Periglacial Processes, 27: 31-42.

Konrad, J.M., Seto, J.T.C., 1991. Freezing of a clayey silt contaminated within organic solvent. Journal of Contaminant Hydrology, 8: $335-355$

Majorowicz, J., 1976. Geothermal parameters of the Krzemianka and Udryń region against the background of the Earth's heat flow in NE Poland (in Polish with English summary). Przegląd Geologiczny, 26: 607-613.

Majorowicz, J., 1984. Problems of tectonic interpretation of geothermal field distribution in the platform areas of Poland. Publications of the Institute of Geophysics, A-13 (160): 149-166.

Marks, L., 2005. Pleistocene glacial limits in the territory of Poland (in Polish with English summary). Przegląd Geologiczny, 53: 988-993.

Michalski, T., 1985. The influence of Pleistocene glaciations on the thickness of the low mineralized water zone in north-eastern Poland. Proceedings of Hydrogeology in the service man. 18th Congress of the International Association of Hydrogeologists, Cambridge: $40-47$
Mojski, J.E., 2005. Ziemie polskie w czwartorzędzie (in Polish). Zarys morfogenezy. Państwowy Instytut Geologiczny, Warszawa.

Mottaghy, D., Rath, V., 2006. Latent heat effects in subsurface heat transport modelling and their impact on palaeotemperature reconstructions. Geophysical Journal International, 164: 236-245.

Petit, J.R., Jouzel, J., Raynaud, D., Barkov, N.I., Barnola, J.M., Basile, I.M., Bender, M., Chappellaz, J., Davis, M., Delaygue, G., Delmotte, M., Kotlyakov, V.M., Legrand, M., Lipenkov, V.Y., Lorius, C., Pépin, L., Ritz, C., Saltzman, E., Stievenard, M., 1999. Climate and atmospheric history of the past 420,000 from the Vostok ice core, Antarctica. Nature, 399: 429-436.

Romanovsky, V.E., Drozdov, D.S., Oberman, N.G., Malkova, G.V, Kholodov, A.L., Marchenko, S.S, Moskalenko, N.G., Sergeev, D.O., Ukraintseva, N.G., Abramov, A.A., Gilichinsky, D.A., Vasiliev, A.A., 2010. Thermal state of permafrost in Russia. Permafrost and Periglacial Processes, 21:136-155.

Ryka, W., Podemski, M., eds., 1998. Geology of the Suwałki Anorthosite Massif (Northeastern Poland). Prace Państwowego Instytutu Geologicznego, 161: 1-89.

Stenni, B., Masson-Delmotte, V., Selmo, E., Oerter, H., Meyere, H., Rothlisberger, R., Jouzel, J., Cattani, O., Falourd, S., Fischer, H., Hoffmann, G., lacumin, P., Johnsen, S.J., Minster, B., Udisti, R., 2010. The deuterium excess records of EPICA Dome C and Dronning Maud Land ice cores (East Antarctica). Quaternary Science Reviews, 29: 146-159.

Svendsen, J.I., Alexanderson, H., Astakhov, V. I., Demidov, I., Dowdeswell, J.A., Funder, S., Gataullin, V., Henriksen, M., Hjort, C., Houmark-Nielsen, M., Hubberten, H.W., Ingólfsson, O., Jakobsson, M., Kjćr, K.H., Larsen, E., Lokrantz, H., Lunkka, J.-P., Lys, A., Mangerud, J., Matioushkov, A., Murray, A., Möller, P., Niessen, F., Nikolskaya, O., Polyak, L., Saarnisto, M., Siegert, C., Siegert, M.J., Spielhagen, R.F., Stein, R., 2004. Late Quaternary ice sheet history of northern Eurasia. Quaternary Science Reviews, 23: 1229-1271.

Szewczyk, J., 2002. Evidences for the Pleistocene-Holocene climatic changes from the deep well temperature profiles from the Polish Lowlands. Proceedings of International Conference: The Earth's Thermal Field and Related Research Methods, Moscow: 271-275.

Szewczyk, J., 2005. Climate changes and their influence on subsurface temperature of the Earth (in Polish with English summary). Przegląd Geologiczny, 53: 77-86.

Szewczyk, J., 2010. Geophysical and hydrogeological aspects of utilization of thermal energy in Poland (in Polish with English summary). Przegląd Geologiczny, 58: 566-573.

Szewczyk, J., 2014. Results of geophysical research for boreholes Kętrzyn IG-1 and Kętrzyn IG-2 (in Polish). Profile Głębokich Otworów Wiertniczych Państwowego Instytutu Geologicznego, 138: $165-177$

Szewczyk, J., Gientka, D., 2009. Terrestrial heat flow density in Poland - a new approach. Geological Quarterly, 53 (1): 125-140.

Szewczyk, J., Nawrocki, J., 2011. Deep-seated relict permafrost in northeastern Poland. Boreas, 40: 385-388.

Szewczyk, J., Gidziński, T., Gientka, D., 2003. Geothermal and hydrogeochemical anomaly at Krzemianka-Udryń area - a remnant of the deep permafrost (in Polish with English summary). Proceedings of the 11th Hydrogeological Symposium, Gdańsk: 229-236,

Szewczyk, J., Gidziński, T., Leśniak, P., 2005. Long lasting effects of the deep-seated Weichselian permafrost in the NE of Poland. Transactions of 2nd European Conference on Permafrost, Potsdam (Germany). 
Szewczyk, J., Nowicki, Z., Gientka, D., 2007. Evaluation of the deep Vistulian permafrost on Polish Lowlands - geothermal and paleohydrogeological implications. Proceedings of the 13th Hydrogeological Symposium, 229-236. Akademia Górniczo-Hutnicza, Kraków-Krynica: 203-211.

Šafanda, J., Szewczyk, J., Majorowicz, J., 2004. Geothermal evidence of very low glacial temperatures on a rim of the Fennoscandian ice sheet. Geophysical Research Letters, 31: 1-4, L07211, doi:10.1029/2004GL019547,
Velichko, A.A., Nechaev, V.P., Baulin, V.V., Belopukhova, E.S., Danilova, N.S., 2002. Map 2. The Late Valdai-Sartan glacial epoch (in Russian). Permafrost. In: Dynamics of Terrestrial Landscape Components and Inner Marine Basin of Northern Eurasia during the Last 130000 Years (ed. A.A. Velichko), 5. GEOS Publishers, Moscow.

Waller, R.I., Murton, J.B., Kristensen, L., 2012. Glacier-permafrost interactions: processes, products and glaciological implications. Sedimentary Geology, 255: 1-28. 